\title{
Development of Wind Energy in India and a Stratagem for Analyzing Performance of Wind Farm Clusters
}

\author{
Aritra D E \\ University of Engineering and Management, Jaipur \\ Gurukul, Sikar Road, NH - 11, Jaipur, Rajasthan - 303807
}

\begin{abstract}
With maturity of stepping-up technologies and immediate requirement for maintaining a healthy environment with minimal price, India is moving towards a bias of generating electricity from renewable resources. Wind energy production, with its relatively safer and positive environmental characteristics, has evolved from a marginal activity into a multibillion dollar industry today. Wind energy power plants, also known as wind farms, comprises of multiple wind turbines. Though there are several wind-mill agglomeration producing energy in different geographical locations across the world, evaluating their performance is a complex task and is an important focus for stakeholders. In this work an attempt is made to estimate the performance of wind clusters employing a multicriteria approach. Multiple factors that affect wind farm operations are analyzed by taking experts opinions, and a performance ranking of the wind farms is generated. The weights of the selection criteria are determined by pairwise comparison matrices of the Analytic Hierarchy Process (AHP). The proposed methodology evaluates wind farm performance based on technical, economic, environmental, and sociological indicators. Both qualitative and quantitative parameters were considered. Empirical data were collected through questionnaire from the selected wind farms of Belagavi district in the Indian State of Karnataka. This proposed methodology is a useful tool for cluster analysis.
\end{abstract}

Keywords: Wind Energy in India, Renewable Energy, Current Scenario, Strategies, Indicators, Wind Farm Clusters.

\section{INTRODUCTION:}

On account of continuous industrial development clubbed with depletion of fossil fuels and emerging environmental consciousness, the demands for alternative energy resources have been increasing exponentially in the 21 st century. With growing demand for energy, increased environmental pollution, and depleting energy sources, human society today faces multiple challenges of transition towards a sustainable development and the poverty eradication. In dealing with sustainable development energy is one of the main factors that must be considered. The concept of sustainable development according to Brundtland report is based on the idea of meeting the needs of the present without compromising the ability of future generations to meet their own needs. In developing economies clean and energy-efficient technologies can contribute to sustainable development and energy security.

Energy planning involves finding a set of sources to meet the energy requirements in an optimal manner. As an alternative means and of meeting global energy demands, renewable energy sources, including solar, wind, mini-hydropower, geothermal, and biomass energy, are receiving increasing attention. Being an affordable and clean energy source, wind energy is among the world's fastest growing renewable energy forms. The challenge for India today is rapid adoption of renewable energy sources to power growing economy at a price that consumers can afford and on a scale large enough to make a major dent in shortages. India has added large-scale conventional power resources, as demand for power has grown since decades. Today there are alternate options available in the form of solar and wind power technologies and renewable energy (RE) resources have become commercially available in the marketplace. This has added additional options for policymakers who are concerned with the technical, economic, and environmental characteristics of a future power system that keeps pace with economic growth.

\section{RENEWABLE ENERGY IN POWER SECTORS}

India with over 1.27 billion population is the seventh largest geography and today ranks fourth among high energy consuming countries in the world. In the past three decades total primary energy consumption has increased manifold from 18 MTOE (in 1980) to 104 MTOE (2011) in India. Also, with the growing economy, the dependence of energy has increased magnanimously due to growing industrialization and the impetus given to infrastructure development. India is importing $79 \%$ of the petroleum it needs and has been heavily relying on imported coal. Therefore it is necessary now that India looks for domestic sources of energy. India's renewable energy potential is very vast and most of it remains untapped. According to recent estimates solar potential is greater than $10,000 \mathrm{GW}$ for India and wind potential could be higher than $2,000 \mathrm{GW}$

To completely utilize the large energy potential, India requires new initiatives from both state and union governments. These new initiatives should be beyond existing policies and programs. Renewable energy contributes about $13 \%$ of the total power generation in India and this contribution is slowly increasing. Grid interactive power generating plants from RE sources constitute $38821 \mathrm{MW}$ with the major share of wind energy plants (25088 MW) followed by biomass/bagasse cogeneration plants $(4688 \mathrm{MW})$, solar photovoltaic (4879 MW), and small hydro (4177 MW). Municipal solid wastes accounts for a very small fraction in power generation [MNRE]. India's overall energy potential is more than the current total energy consumption. India's renewable energy 
program is the biggest and most extensive. The Government of India is committed to provide a conducive environment for harnessing offshore wind energy in India. The Government envisions carrying forward the development of offshore wind energy in the country, to overcome the existing barriers and to create technological and implementation capabilities within the country. The broad vision behind the integrated energy policy is to meet the demand for energy services of all sectors. The Ministry of New \& Renewable Energy (MNRE), Government of India, has set a target of achieving overall renewable energy installed capacity of 41,400 MW by 2017 .

\section{GROWTH OF WIND ENERGY}

India's target of achieving $175 \mathrm{GW}$ of renewable energy capacity by 2022 might appear ambitious, but it is crucial as it will have a positive impact on the country's economic growth, energy security and the fight against climate change. Financing is emerging as the key challenge to this vision, slowing down the pace of growth; as of December 2019, over 50 percent of the 2022 target is yet to be achieved. This brief outlines India's existing renewable energy financing landscape and identifies the challenges therein. The most critical issue facing India's financing framework is the lack of innovative financing options that will offer larger sums at lower interest rates and for longer durations. Overall, sound financing will boost the number and size of the projects, ultimately translating to accelerated renewable energy growth.

\section{WIND FARM OR WIND CLUSTER}

Wind farms are areas where many large wind turbines have been grouped together. They "harvest" the power of the wind. These large turbines look a bit like super-tall windmills. A large wind farm can have hundreds of wind turbines spread out over hundreds of miles. The land between the turbines may be used for other purposes, such as regular farming. Some wind farms are also located near bodies of water. There, they take advantage of winds that blow across lakes or oceans.

Earth's shape and rotation work with the Sun's uneven heating of the atmosphere to make winds.

Wind farms are built in areas known to be especially breezy on a regular basis. The winds turn the blades of the turbines. Then, the turbines turn the energy of the wind into mechanical power. Generators then turn the mechanical power into_electricity. That electricity is then used to power homes.

We can think of a wind turbine as the opposite of a fan. A fan uses electricity to make wind. Wind turbines do the opposite: they use the wind to make electricity! As the wind turns the blades of a wind turbine, the blades cause a shaft to spin. The spinning shaft connects to a generator that creates electricity.

There are plenty of good reasons. Wind energy is free and renewable. Unlike most power plants, wind farms don't emit contamination or greenhouse gases.

However, wind farms can cost a lot of money to set up. Over time, though, their cost is competitive with other types of generating systems. Unfortunately, we can't make the wind blow whenever you want it to. That means wind farms can't always meet electricity needs on demand.
Over time, researchers believe new technologies will make wind power even more popular. They believe people may one day store wind power in batteries for on-demand use.

\section{REVIEW OF WIND FARM CLUSTER PERFORMANCE}

Today wind turbine generators (WTGs) are almost comparable to conventional units of power generation in terms of both cost and capacity ratings due to the development in wind technology. The performance of a WTG is affected by reliability, power factor, technical availability, and capacity factor. Doubling the wind speed magnifies the power developed by 9 times, as power is proportional to cube of velocity. Also wind velocity variation has an impact on the economics and smooth running of the wind energy conversion system. Today variable speed generations are available in markets which are cost effective. Power density and annual mean wind speed need to be measured in order to assess the long term trend of wind speed. The annual energy output at a location also depends on interconnection with electric networks, height of installation, effect of wind gusting, and so forth. According to expert's prediction, by the year 2021 wind power can capture 5\% of the world energy market with improved technologies and superior economics.

There are many notable studies on development and performance of wind farms in literature. Lee et al. constructed a comprehensive evaluation model to select a suitable location for developing a wind farm in Taiwan. Şenel et al. performed a study to determine the current position of wind energy in Turkey and policies to increase the usage of wind energy. Sholapurkar and Mahajan carried a review on Maharashtra's (India) wind energy progress, considering factors such as wind project installations, total capacity, declared wind sites, and wind power density at different altitudes. Barin et al. developed a multi-criteria decision exploration (MCDE) to evaluate the operation of the renewable energy sources-wind generators, micro turbines, photovoltaic cells, and fuel cells. Himri et al. worked on wind farm development in Algeria. Wind speed data over a period of almost 10 years was utilized, in order to assess the energy output of a wind farm in terms of gross energy, renewable energy delivered, specific yield, and wind farm capacity factor. Phadke et al. assess the techno economic onshore wind potential in India at three hub heights: $80 \mathrm{~m}$, $100 \mathrm{~m}$, and $120 \mathrm{~m}$. Nemes and Munteanu developed a probabilistic model for capacity factor and technical efficiency estimation in the wind farms of North-East of Romania. A techno economic evaluation of small wind electric generator (SWEG) projects for providing decentralized power supply in remote locations in India is presented by Nouni et al. Also Rajakumar and Nagesha estimated the performance of a windmill cluster adopting a multiple-criteria approach. The methodology was implemented by collecting empirical data from three wind-mill clusters located at Chitradurga, Davangere, and Gadag in the southern Indian State of Karnataka.

To improve the reliability of the system and to rectify the failures it is important to analyze the performance of a wind farm. The WPD which is a prime parameter varies with different locations as well as with seasons in India. From April 
to September high WPD is observed and during October to December low WPD is observed. The energy generation at a site varies due to speed of the wind speed and other technical factors. The power curve is the most important performance criterion. On the basis of the power curve the annual energy output can be calculated for a given site which indirectly gives the Capacity Utilization Factor (CUF) of a wind farm. Other factors which describe the performance of a wind farm are site factor, transmission losses, net energy output, individual WTG performance in the cluster, and so forth. Further, parameters like return on investment or cost/unit, machine availability, and grid connectivity are also relevant in estimating performance of any wind farm. A lot of quantitative and qualitative factors are involved in decision making process. Energy evaluations may involve both quantitative and qualitative factors. These should cover technical, economic, environmental, and socioeconomic factors. In the earlier studies multiple evaluation criteria were used which include (a) technical (efficiency, primary energy ratio, safety, reliability, and maturity); (b) economic (investment cost, operation and maintenance cost, fuel cost, net present value, payback period, service life, equivalent annual cost, etc.); (c) environmental $\left(\mathrm{CO}_{2}\right.$ emission, emission, $\mathrm{SO}_{2}$ emission, particles emission, land use, noise, etc.); and (d) social (social acceptability, job creation, social benefits, etc.) parameters.

\section{DETAILS OF THE WIND FARM UNDER STUDY}

Karnataka is one of the top five states in India having high potential of wind energy generation [35]. It has about $30,000 \mathrm{MW}$ of officially estimated renewable energy (RE) potential, making it one of the country's top five RE-rich states. Out of $15.0 \mathrm{GW}$ installed electricity generating capacity in Karnataka, RE sources contribute for about $5.1 \mathrm{GW}$ or $30 \%$ [36]. By March 2016, the total allotted wind energy generation capacity to various groups was $13983 \mathrm{MW}$. But the commissioned capacity stands at $2916 \mathrm{MW}$ (20.84\%) only, which is $20 \%$ of allotted capacity. $3427 \mathrm{MW}$ of allotted capacity was cancelled due to several reasons.

The district of Belagavi is located in north western part of the state of Karnataka. It has an average elevation of $751 \mathrm{~m}$. The Belagavi district wind farm cluster consists of 318 wind turbine generators with a total installed capacity of $319.3 \mathrm{MW}$. The installed capacities of wind energy ranged from $250 \mathrm{~kW}$ to $2 \mathrm{MW}$ and cost per MW varies for different developers. In Belgaum district wind cluster, the wind farms are located in many places, namely, Chikkodi, Ramdurg, Raibag, Saundatti, Hukkeri, and Belagavi. The wind potential variability lies in the range of 4.27 to $6.75 \mathrm{~m} / \mathrm{s}$ annual wind velocity with wind power density (WPD) ranging from $170 \mathrm{~W} / \mathrm{m}^{2}$ to $350 \mathrm{~W} / \mathrm{m}^{2}$ at $50 \mathrm{~m}$ hub height. The total installed capacity is $319.3 \mathrm{MW}$ as on July 2015 with 318 total WTGs [36]. The district of Belagavi is one among the top five districts having higher potential for wind energy generation. For the analysis a questionnaire-based research survey was conducted. Opinions and judgments were collected from wide variety of experts and stakeholders. All respondents were knowledgeable about the power sector and were familiar with clean, efficient, and renewable energy generation technologies and the barriers hindering their widespread diffusion and adoption.

\section{AHP METHODOLOGY FOR WIND CLUSTER PERFORMANCE ANALYSIS}

One of the main objectives of this work is to develop a methodology to evaluate the performance of wind farm clusters. For this purpose the Analytic Hierarchy Method (AHP) has been employed. In AHP methodology initially problem is defined with the main objective. In the next step, the criteria are identified and the problem is structured in a hierarchy. Then each element is compared on a 1-9 scale (ranging from equal importance to extreme importance) and finally calculations are done to find the max. Eigenvalue, consistency index $(\mathrm{CI})$, consistency ratio $(\mathrm{CR})$, and normalized values for each criteria. Finally decision is taken if the calculated max. Eigenvalue, CI, and CR are satisfactory. The consistency of the judgments is checked on the basis of consistency ratio (CR) which should be less than 0.1 . The advantage of AHP is to find priority weights through paired comparison of attributes through a qualitative and quantitative approach.

\section{WIND FARM CLUSTER PERFORMANCE}

In the present work, an attempt is made to evaluate the windmill cluster performance through multicriteria approach. The index to measure the performance is termed as CIOP-Cluster Index of Performance. The usage of energy is closely associated with human activities as well as sustainability issues and hence an energy system can provide lead indicators for sustainable development. The selection of indicators is the primary step in wind farm cluster performance. Several studies have been carried out in the past using various MCDM methodologies such as AHP, VIKOR, fuzzy, and axiomatic design method, on assessment of sustainability indicators. The chosen indicators in the present work include technical, economic, environmental, and social components.

The evaluation criteria considered under each indicator are presented below:

(i)Technical. Energy production capacity, feasibility, risk, duration of preparation and implementation phase, technological maturity, reliability, safety, and local technical knowhow (ii) Economical. Investment cost, implementation cost, operation and maintenance cost, service life, economic value (PW, IRR, and PBP), availability of funds (iii) Environmental. Pollutant emission $\left(\mathrm{CO}_{2}\right)$, need of waste disposal, land requirements (iv) Sociopolitical. Social acceptability, policy objectives, labor impact, political acceptance, and compatibility with national energy

Stakeholders involved are engineers working in wind farms, wind farm developers, Government officials from energy department, and a few selected residential people near the wind farms. To obtain the relevant data in each wind farm, the stakeholders are consulted through a set of structured questionnaire. The data varied from cluster to cluster and also between WTGs within a cluster. A total of 10 parameters were considered for each criterion including five subject oriented 
and five objective question-responses. The methodology is implemented by collecting empirical data from the wind-mill clusters located at Chikkodi, Saundatti, Raibag, and Belagavi in the Belagavi district of Karnataka which has been chosen for study.

\section{CRITERIA FOR EVALUATING WIND FARM CLUSTER PERFORMANCE}

Though there are many parameters relevant in evaluating the performance of wind farms, a proper methodology comprising important factors is required to be developed to estimate the wind-mill cluster performance. The following four indicators, namely, technical, economic, environmental, and social indicators, to evaluate the performance of a wind farm were recommended by the World Energy Council (WEC). Further, a total of ten parameters under each of the four proposed indicators were considered in this work to take into account various dimensions of each indicator. Out of these parameters, five are quantitative in nature and remaining five are qualitative response types.

\section{INDICATORS OF TECHNICAL PERFORMANCE (ITEP)}

The total energy generated during the nominal period to the total potential energy that can be generated during the same period is termed as capacity factor (CF) and is measured in $\%$. The amount of energy generated during the nominal period to the swept rotor area is represented by specific energy production $\left(\mathrm{kWh} / \mathrm{m}^{2}\right)$. Equivalent full load hours are the availability of number of annual hours of WTGs. The plant availability factor represents the total operating hours of wind plant during the period to that of total length (in hrs.) of operation of each WTG in wind farms. The wind conditions data is very important to decide type and rating of WTGs that can be installed in any wind farm as it depends on the wind velocity and WPD of a particular region. The topography factor deals with the viability of installing different rating and type of WTGs, based on the topography and siting of them. The design aspect and its appropriateness in the cluster are measured using the factor, Development of Appropriate Design Criteria, Specification \& Standards. The factor, full scale testing prior to commercial introduction, needs the real groundwork to be carried out in order to manufacture components of WTG as per the design criteria and standards, and it should also be tested prior to the practical implementation. The last two parameters (condition monitoring system and power evacuation) are very important to maintain sustained amount of power generation in the wind farm and its evacuation to the nearby grid to ensure economic feasibility. While the first five parameters values are obtained through quantitative computations the subsequent five parameter values are obtained on a 1-5 scale using stakeholder responses and value judgments.

\section{INDICATORS OF ECONOMIC PERFORMANCE (IECP)}

The parameters under economic performance criteria (IEcP) and the corresponding score are presented in Table $\underline{3}$. The turnover ratio is the ratio of total annual revenue generated to the total initial investment including WTG cost and up to grid connection cost. Internal rate of return (IRR) is the interest rate at which net present worth (NPW) becomes zero. Payback period (PBP) is the minimum time for any investor to get back his investment, if it is less this means the investor comes forward to invest more in WETs. Labour productivity is measured in terms of total annual revenue generated to the total annual expenditure on Human Resources (HR). Maintenance charges cover expenses towards annual Operation \& Maintenance (O\&M) of WTG and accessories in order to keep up the machine availability to the maximum extent. As the variation of wind velocity and its distribution leads to the variation of annual energy output of any wind farm, it is captured in the form of site factor. Increase in feed-in tariffs (FIT) attracts the investors and motivates them to invest more. Favorable situation should be created in order to support the chance of repowering, if any, in the wind farm. Final parameter is an important economic aspect since the good accessibility to the cluster saves time, money, and so forth.

\section{INDICATORS OF ENVIRONMENTAL PERFORMANCE} (IENP)

The various parameters covered under the environmental criterion (IEnP). First two parameters indicate the contribution made to the reduction of greenhouse gas (GHG) emissions concentrating on the major pollutant $\mathrm{CO}_{2}$, on an annual basis, and other emissions like NOx and SOx, along with $\mathrm{CO}_{2}$ for the whole life cycle of WTGs. The third parameter considers minimum distance of WTG away from dwellings while the fourth is about the noise from WTGs. The fifth parameter records the number of birds killed during the development and maintenance of wind farm and the sixth is about shadow casting to nearby residence. Third, fourth, and sixth parameters capture the safety aspects by maintaining minimum distance away from nearby dwellings to avoid landscape, sound, and shadow flickering. Seventh, eighth, and ninth parameter indicate the importance of protecting historical heritage and environment by assessing wind farm's effects on flora and fauna, climate change, and so forth. Final parameter is relevant when the wind farm is nearby the dwellings where there is interruption for communication systems like mobile towers, antennas, and so forth.

\section{INDICATORS OF SOCIOLOGICAL PERFORMANCE (ISOP)}

Ten parameters which are used in evaluating the sociological performance (ISoP) of a wind farm along with the score for the clusters. First parameter considers the number of jobs that a wind farm can generate from the manufacturing to the erection and commissioning stage and also during maintenance. Number of households electrified due to the development of wind farm is covered in the second parameter. Third parameter is very important for the smooth functioning and development of wind energy farm activities by ensuring safety. Fourth parameter is vital for landowners and nearby villagers who have given land for setting up the wind farm. Fifth parameter deals with the contribution made towards educational and cultural development of locality. Sixth parameter considers the 
degree of improvement in tourism due to the attraction of wind farm. The degree of damage caused by wind farm to nearby environment, people, and so forth is covered by the seventh parameter. The last three parameters try to figure out the positive effect of wind farm on the development of agricultural and rural industrialization, poverty alleviation, and migration/birth rates of nearby people.

\section{EVALUATION OF CLUSTER INDEX OF PERFORMANCE (CIOP)}

Different performance indicators have been used in this work to compare the performance of the different wind clusters. This is accomplished by developing an index to evaluate the performance called "Cluster Index of Performance (CIOP)".Analytic Hierarchy Process (AHP) under multicriteria framework is used as a tool to evaluate CIOP. The advantage of AHP is that it helps to develop a theory and then provides a methodology for modeling the unstructured problems in the economic, technical, social, and management sciences. By its flexible and powerful weighed scoring decision making process, AHP helps to set priorities and makes the best decision when both qualitative and quantitative aspects of a decision need to be considered. AHP engages decision makers in breaking down a decision into parts, proceeding from the goal (at the top level) to criteria (at the subsequent level). The decision makers then make simple pairwise comparison judgments through the hierarchy to arrive at overall priorities for the criteria.

\section{CLUSTER PERFORMANCE ANALYSIS UNDER THE AHP FRAMEWORK}

A cluster performance analysis framework is developed in this section utilizing the existing literature pertaining to the performance analysis and discussion with experts in the field of wind energy. Four important criteria are considered to obtain the CIOP. The framework is prepared in a hierarchical structure, as the analysis is carried out using the multiplecriteria under AHP. It has two levels comprising the goal and criteria. Level 1 is the main goal which can be obtained by summating the scores of four performance indicators. Prior to this, the relative importance/priority of the four performance indicators (level 2) are obtained with respect to the goal (CIOP) through pairwise comparisons using AHP. The pairwise comparisons for the wind farms and are obtained by computing means of all the individual pairwise comparisons of responses from various stakeholders from each wind farm. Subsequently, by dividing each matrix element by the sum of respective column elements (normalization of column) and then by calculating the arithmetic mean of each row the priority is obtained. The stakeholders give maximum priority $(52 \%)$ to ITeP followed by ISoP (23\%). The IEcP (16\%) and IEnP (8\%) get the next two positions. It is an established fact that technical performance is the most important aspect in deciding the cluster performance of a wind cluster and the same is reflected by the stakeholders. Economic aspects are rated as the third most important criteria followed by social factors. Low weight of the environmental factor indicates the least orientation of the stakeholders towards environmental performance indicators, as most of the WTGs in the selected wind farms are in barren hilly regions.

\section{CALCULATION OF CIOP AND COMPARISON OF THE WIND FARMS}

The first five are quantitative ones and the last five are qualitative in nature. Since all the ten parameters were having different units, getting a total score becomes difficult as they cannot be added. To make quantitative values compatible with qualitative parameters, the quantitative values are converted into a scale of $1-5$. Finally, to get the total score under the criteria, the sum of the ten values inside the parenthesis is multiplied by the weight of the respective criterion. The final performance index, that is, the CIOP score of the wind farms. From this table it is evident that the Chikkodi wind farm cluster is the best performing cluster with CIOP of 38.46 followed by Saundatti, Raibag, and Belagavi clusters. Wind energy has been used for many thousands of years, but only in the past 35 years it has come on a significant scale to be integrated into the modern energy supply. Research and development has already helped greatly to reduce the cost of wind energy, although there is scope to further lower capital costs, improve reliability, and expand the range of applicability of wind energy systems. To maximize the usage of this technology, proper sites should be investigated and wind turbines should be installed. Wind energy can play a significant role in strengthening the energy security of a country by decreasing the energy dependency, avoiding greenhouse gas emissions and by creating thousands of jobs.

\section{CONCLUSIONS}

It is foreseeable that the move towards generating electricity from renewable wind resources will become the trend in future years. There is a strong relationship between the availability of energy and economic activity of a country. Multicriteria decision making methods are becoming popular in helping governments and companies in evaluating energy sector plans, policies, projects and site selections issues, and so forth. Wind energy is a major source of power in over 70 countries globally. There is a huge and growing global demand for wind power, which can be installed quickly and virtually everywhere in the world.

Considering wind farm clusters as power plants comprised of multiple wind turbines, the current study focused on the determination of the best performing wind cluster. The primary focus was to develop a methodology to evaluate the performance of a wind farm cluster using multicriteria approach. Performance estimation among clusters has been made using AHP methodology. The proposed methodology develops an index of performance to evaluate the best performing wind farm cluster based on multicriteria decision making. Four evaluation criteria were taken into consideration according to the given literature, namely, technical, environmental, economic, and social indicators for development of Cluster Index of Performance (CIOP). Both qualitative and quantitative parameters were considered. The results of analysis suggest that the Chikkodi wind farm cluster as the best performing one, followed by Saundatti, Raibag, and 
then Belagavi farm. In the future research other multicriteria decision making techniques such as TOPSIS, VIKOR, and ANP can be used and their results can be compared with the proposed methodologies. This study has several notable strengths. First, in this study the qualitative factor in decision making process transformed to quantitative factors. Second, the survey is made by face to face to reduce questionnaire mistakes. Also, this study has certain limitations. First, data are taken from a small group in energy sector and the results in this study cannot be generalized. Second, the index may change by adding other clusters.

\section{APPENDIX}

\section{A. Indicators of Technical Performance}

(a)Capacity factor $(\mathrm{CF}$ in $\%)=$ total energy production during the normal period/potential energy production during the period.

(b)Specific energy production $\left(\mathrm{kWh} / \mathrm{m}^{2}\right)=$ total energy production during the normal period/swept rotor area.

(c) Equivalent full load hours (h) = annual energy production/rated power.

(d) Plant availability factor (in \%) = total hrs. of operation of plant during the period $\times 100 /$ total length of the period (hrs.)

(e)Wind resources or wind conditions during the period (in $\mathrm{m} / \mathrm{s})$

While the first five parameters values are obtained through quantitative computations the subsequent five parameters are obtained on a 1-5 scale using stakeholder responses and value judgments. This analysis varies with each cluster.

\section{B. Indicators of Economic Performance}

(a) Turnover ratio $=$ annual revenue (Rs in crores)/total investment including WTGs and grid connections

(b)Internal rate of return (IRR) is the interest rate at which NPW becomes zero, that is, the value where the NPW curve crosses the interest axis in a NPW with time plot

(c) Payback period $(\mathrm{PBP})=$ initial investment/ (annual revenue - O\&M charges)

(d)Labor productivity = annual revenue/annual HR expenditure

(e) Maintenance factor $=$ annual revenue/annual O\&M cost

\section{Indicators of Environmental Performance}

(a)Contribution to the reduction of GHG emissions (avoided $\left.\mathrm{CO}_{2} \mathrm{t} / \mathrm{MW} / \mathrm{y}\right)$

(b)Pollutant emissions during life cycle; $(\mathrm{g} / \mathrm{kWh})=$ quantities of $\mathrm{CO}_{2}$, and emitted per $\mathrm{kWh}$ during the whole life cycle of the plant

The above parameters are evaluated by considering the data that $1 \mathrm{MW}$ of power generation from coal thermal produces 19 ton of $\mathrm{CO}_{2}, 136 \mathrm{~kg}$ of $\mathrm{SO}_{2}, 7$ ton of fly ash, and $60 \mathrm{~kg}$ of particulate matter per day, assuming an average plant load factor (PLF) of $75 \%$.

\section{Indicators of Sociological Performance}

(a) Jobs created by the plant: number of jobs created by $1 \mathrm{MW}$ capacity WTG at different stages including manufacturing, installation, O\&M period, and so forth (b) Providing access to electricity: number of households having access to the electricity produced by a $1 \mathrm{MW}$ plant

(c) Industrial safety accident rate (SAR): number of accidents for all utility personnel assigned to plant.

\section{REFERENCES}

[1] Sustainable Development: From Brundtland to Rio 2012 Background Paper prepared for consideration by the High Level Panel on Global Sustainability at its first meeting, September 2010.

[2] F. Urban, Sustainable energy for developing countries: modeling transitions to renewable and clean energy in rapidly developing countries [M.S. thesis], 2008.

[3] V. Del Rosario, Community stakeholder management in wind energy development projects: a planning approach [M.S. thesis], 2007.

[4] R. B. Hiremath, S. Shikha, and N. H. Ravindranath, "Decentralized energy planning; modeling and application-a review," Renewable and Sustainable Energy Reviews, vol. 11, no. 5, pp. 729-752, 2007. View at: Publisher Site | Google Scholar

[5] NITI Aayog, Report on India's Renewable Electricity Roadmap 2030 Toward Accelerated Renewable Electricity Deployment, NITI Aayog, New Delhi, India, 2015

6] EIA, Annual Energy Outlook 2013, With Projections to 2040, EIA2013, U.S. Energy Information Administration, Office of Integrated and International Energy Analysis, U.S. Department of Energy, Washington, DC, USA, 2013.

[7] Reenergizing India, Policy, Regulatory and Financial Initiatives to Augment Renewable Energy Deployment in India: Climate Parliament-2014, IDAM Infrastructure Advisory Private, New Delhi, India, 2014.

[8] MNRE, National Offshore wind Energy Policy, Ministry of New and Renewable Energy. Government of India, 2015, http://mnre.gov.in/information/policies-2/.

[9] H. Jami, "India's wind power potential," Tech. Rep., Ministry of New and Renewable Energy, 2015. View at: Publisher Site | Google Schola

[10] R. B. Sholapurkar and Y. S. Mahajan, "Review of wind energy development and policy in India," Energy Technology \& Policy, vol. 2, no. 1, pp. 122-132, 2015. View at: Publisher Site | Google Scholar

[11] Wwindea-New Record in Worldwide Wind Installations, http://www.wwindea.org/the-world-sets-new-wind-installationsrecord-637-gw-new-capacity-in-2015/.

[12] J. Hossain, V. Sinha, and V. V. N. Kishore, "A GIS based assessmen of potential for windfarms in India," Renewable Energy, vol. 36, no. 12, pp. 3257-3267, 2011. View at: Publisher Site | Google Scholar

[13] WinDForce, Report on India's Wind Power Potential Submitted to MNRE, WinDForce Management Services Pvt. Ltd., Gurgaon, India CSTEP, Bengaluru, India; Shakti Foundation, New Delhi, India, 2015.

[14] Twelfth five year plan 2012-2017, II-Economic sectors, Planning Commission (Government of India), Sage, 2013.

[15] C. Mehra and J. Hossain, Barriers to Accelerating Wind Energy in India, 2015, http://case-bharat.org/dox/Wind\%20POS\%20Paper.pdf.

[16] M. N. R. E. Varsha Joshi, 2014, http://www.slideshare.net/varshajoshi95/wind-power-in-india-anongoing-success-story-40134571.

[17] T. V. Ramachandra and G. Hegde, "Energy trajectory in India: challenges and opportunities for innovation," Journal of Resources Energy and Development, vol. 12, no. 1-2, pp. 1-24, 2016. View at: Publisher Site | Google Scholar

[18] O. Badran and E. Abdulhadi, "Evaluation of factors affecting wind power generation in Jordan," in Proceedings of the 7th Asia-Pacific Conference on Wind Engineering, Taipei, Taiwan, November 2009. View at: Google Scholar

[19] K. Bruce Newbold and M. Mckeary, Wind energy power pantsreview and analysis [M.S. thesis], Institute of Environment \& Health (MIEH), 2010 http://www.mcmaster.ca/mihe/documents/publications/Wind_Farms_ 2010.pdf.

[20] A. H. I. Lee, H.-Y. Kang, and C.-C. Chang, "An integrated interpretive structural modeling-fuzzy analytic network processbenefits, opportunities, costs and risks model for selecting technologies," International Journal of Information Technology and Decision 
Making, vol. 10, no. 5, pp. 843-871, 2011. View at: Publisher Site Google Scholar

[21] O. Ozgener and L. Ozgener, "Exergy and reliability analysis of wind turbine systems: a case study," Renewable and Sustainable Energy Reviews, vol. 11, no. 8, pp. 1811-1826, 2007. View at: Publisher Site Google Scholar

[22] J. A. Baroudi, V. Dinavahi, and A. M. Knight, "A review of power converter topologies for wind generators," Renewable Energy, vol. 32 no. 14, pp. 2369-2385, 2007. View at: Publisher Site | Google Scholar

[23] T. L. Acker, S. K. Williams, E. P. N. Duque, G. Brummels, and J. Buechler, "Wind resource assessment in the state of Arizona: inventory, capacity factor, and cost," Renewable Energy, vol. 32, no. 9, pp. 1453-1466, 2007. View at: Publisher Site | Google Scholar

[24] G. M. J. Herbert, S. Iniyan, E. Sreevalsan, and S. Rajapandian, "A review of wind energy technologies," Renewable and Sustainable Energy Reviews, vol. 11, no. 6, pp. 1117-1145, 2007. View at: Publisher Site | Google Scholar

[25] A. H. I. Lee, H. H. Chen, and H.-Y. Kang, "Multi-criteria decision making on strategic selection of wind farms," Renewable Energy, vol. 34, no. 1, pp. 120-126, 2009. View at: Publisher Site | Google Scholar

[26] B. Şenel, M. Şenel, and L. Bilir, "Role of wind power in the energy policy of Turkey," Energy Technology \& Policy, vol. 1, no. 1, pp. 123 130, 2014. View at: Publisher Site | Google Scholar

[27] A. Barin, L. N. Canha, and A. da Rosa Abaide, "Multicriteria analysis of the operation of renewable energy sources taking as basis the AHP method and fuzzy logic concerning distributed generation systems," The Online Journal on Electronics and Electrical Engineering, vol. 1 no. 1, pp. 52-57. View at: Google Scholar

[28] Y. Himri, A. Boudghene Stambouli, and B. Draoui, "Prospects of wind farm development in Algeria," Desalination, vol. 238, no. 1-3, pp. 130-138, 2009. View at: Publisher Site | Google Scholar

[29] A. Phadke, R. Bharvirkar, and J. Khangura, Reassessing Wind Potential Estimates for India: Economic and Policy Implications, Environmental Energy Technologies Division, International Energy Studies, 2012

[30] C. Nemes and F. Munteanu, "The wind energy system performance overview: capacity factor vs. technical efficiency," International Journal of Mathematical Models and Methods in Applied Sciences, vol. 1, no. 5, pp. 159-166, 2011. View at: Google Scholar

[31] M. R. Nouni, S. C. Mullick, and T. C. Kandpal, "Techno-economics of small wind electric generator projects for decentralized power supply in India," Energy Policy, vol. 35, no. 4, pp. 2491-2506, 2007. View at: Publisher Site | Google Scholar

[32] D. G. Rajakumar and N. Nagesha, "Estimating wind mill cluster performance: a multicriteria approach," Journal of Sustainable
Manufacturing and Renewable Energy, vol. 2, no. 3-4, pp. 93-107, 2013. View at: Google Scholar

[33] O. Demirtas, "Evaluating the best renewable energy technology for sustainable energy planning," International Journal of Energy Economics and Policy, vol. 3, pp. 23-33, 2013. View at: Google Scholar

[34] T. Kaya and C. Kahraman, "Multicriteria renewable energy planning using an integrated fuzzy VIKOR \& AHP methodology: the case of Istanbul," Energy, vol. 35, no. 6, pp. 2517-2527, 2010. View at: Publisher Site | Google Scholar

[35] NRDC - Council for energy environment and water and SHAKTI Foundation-Issue paper A Second Wind for India's Energy Market: Financing Mechanisms to Support India's National Wind Energy Mission, August 2014.

[36] KREDL-Karnataka Renewable Energy Development Ltd, http://www.kredlinfo.in/.

[37] T. L. Saaty, The Analytic Hierarchy Process: Planning, Priority Setting, Resource Allocation, Mcgraw-Hill International Book Company, New York, NY, USA, 1980. View at: MathSciNet

[38] T. L. Saaty, "How to make a decision: the analytic hierarchy process," European Journal of Operational Research, vol. 48, no. 1, pp. 9-26, 1990. View at: Publisher Site | Google Scholar

[39] S. D. Pohekar and M. Ramachandran, "Application of multi-criteria decision making to sustainable energy planning - a review," Renewable and Sustainable Energy Reviews, vol. 8, no. 4, pp. 365381, 2004. View at: Publisher Site | Google Scholar

[40] A. Kemmler and D. Spreng, "Energy indicators for tracking sustainability in developing countries," Energy Policy, vol. 35, no. 4 pp. 2466-2480, 2007. View at: Publisher Site | Google Scholar

[41] G. Wang, Y. Wang, and T. Zhao, "Analysis of interactions among the barriers to energy saving in China," Energy Policy, vol. 36, no. 6, pp. 1879-1889, 2008. View at: Publisher Site | Google Scholar

[42] N. Nagesha and P. Balachandra, "Barriers to energy efficiency in small industry clusters: multi-criteria-based prioritization using the analytic hierarchy process," Energy, vol. 31, no. 12, pp. 1633-1647, 2006. View at: Publisher Site | Google Scholar

[43] S. Peribesh, Biodiversity-Ecosystems Management and the Green Economy, State Pollution Control Board, Bhubaneswar, India, 2010. 